\title{
Analisis Faktor Klinik terhadap Kualitas Hidup Pasien Hemodialisis di RSUD dr. Loekmono Hadi Kudus
}

\author{
Nafiah Adiningrum ${ }^{1 *}$, Tri Murti Andayani ${ }^{2}$, Susi Ari Kristina ${ }^{3}$ \\ ${ }^{1}$ Program Studi Magister Farmasi Klinik, Fakultas Farmasi, Universitas Gadjah Mada, Yogyakarta, Indonesia \\ ${ }^{2}$ Departemen Farmakologi, Fakultas Farmasi, Universitas Gadjah Mada, Yogyakarta, Indonesia \\ ${ }^{3}$ Departemen Farmasetika, Fakultas Farmasi, Universitas Gadjah Mada, Yogyakarta, Indonesia
}

*Corresponding author: nafiah.adiningrum.na@gmail.com

Submitted: 1 Mei 2020

Accepted: 16 Juni 2020

Published: 27 April 2021

\begin{abstract}
Background: Chronic kidney disease (CKD) and hemodialysis have a negative impact on HRQoL patients. HRQoL assessment is important to evaluate the quality of healthcare and treatment. Objective: To assess the patient's HRQoL status and determine clinical factors that influence the quality of life of hemodialysis patients at RSUD dr. Loekmono Hadi. Methods: This was a cross sectional study with total sampling techniques in routine hemodialysis patients who meet the inclusion criteria. Sociodemographic and clinical factors used were comorbidities, time on hemodialysis, hemoglobin, urea and creatinine levels obtained from medical records, quality of life was assessed using KDQoL-SF36 consisting of three domains. Description of quality of life based on sociodemographic were analyzed using Independent sample t-tests or Mann-whitney test and one-way ANOVA or Kruskal-walis test. Analysis of clinical factors that affect the quality of life using Spearman correlation coefficient and logistic regression. Results: The average score of quality of life in 60 subjects was $63.20 \pm 17.05$, while the score for the domain of kidney disease, physical and mental health was $74.52 \pm 9.83 ; 47.41 \pm 25.09$ and $67.68 \pm 20.10$. Clinical factors were weakly correlated with the average quality of life score except for time on hemodialysis variable to the physical health domain $(r=0.319)$. Logistic regression analysis showed that there were no clinical factors that most significantly affected $(p>0.05)$. Conclusion: The clinical measurements were important information to the physicians regarding therapeutic outcomes, but these parameters weakly correlated with HRQoL. HRQoL assessment was needed as a measure of dialysis adequacy and collaboration of health workers to improve patient HRQoL.
\end{abstract}

Keywords: clinical factor, quality of life, hemodialysis, KDQoL-SF36

\begin{abstract}
Abstrak
Pendahuluan: Penyakit ginjal kronik (PGK) dan hemodialisis berdampak negatif terhadap kualitas hidup pasien. Penilaian HRQoL penting dilakukan sebagai evaluasi terhadap kualitas layanan kesehatan dan efektivitas terapi. Tujuan: Untuk menilai status HRQoL pasien dan mengetahui faktor klinik yang berpengaruh terhadap kualitas hidup pasien hemodialisis di RSUD dr. Loekmono Hadi. Metode: Cross sectional dengan teknik total sampling pada pasien hemodialisis rutin yang memenuhi kriteria inklusi. Data sosiodemografi dan faktor klinik yang digunakan yaitu komorbid, durasi menjalani hemodialisis, kadar hemoglobin, ureum, dan kreatinin diperoleh dari rekam medik, sedangkan data kualitas hidup dinilai menggunakan kuesioner KDQoL-SF36 yang terdiri dari tiga domain. Gambaran kualitas hidup berdasarkan karakteristik sosiodemografi dianalisis menggunakan Independent sample t-test atau Mann-whitney test dan one-way ANOVA atau Kruskal-walis test. Analisis faktor klinik yang berpengaruh terhadap kualitas hidup menggunakan koefisien korelasi Spearman dan regresi logistik. Hasil: Skor rata-rata kualitas hidup pada 60 subjek penelitian sebesar 63,20 \pm 17,05, sedangkan skor untuk domain penyakit ginjal, kesehatan fisik dan mental adalah 74,52 $\pm 9,83 ; 47,41 \pm 25,09$ dan 67,68 $\pm 20,10$. Faktor klinik berkorelasi lemah terhadap rata-rata skor domain kualitas hidup kecuali pada variabel durasi menjalani hemodialisis terhadap domain kesehatan fisik $(r=0,319)$. Analisis regresi logistik menunjukkan tidak terdapat faktor klinik yang secara signifikan paling berpengaruh terhadap kualitas hidup pasien $(p>0,05)$. Kesimpulan: Hasil pengukuran klinik
\end{abstract}


merupakan informasi penting bagi dokter untuk melihat luaran terapi, namun parameter tersebut berkorelasi lemah terhadap HRQoL. Penilaian HRQoL diperlukan sebagai ukuran kecukupan dialisis dan kolaborasi tenaga kesehatan untuk meningkatkan HRQoL pasien.

Kata kunci: faktor klinik, kualitas hidup, hemodialisis, KDQoL-SF36

\section{PENDAHULUAN}

Penyakit Ginjal Kronik (PGK) merupakan masalah kesehatan dunia yang terus berkembang karena prevalensi, morbiditas, mortalitas, dan biaya perawatan yang tinggi (Dehesa-lópez dkk., 2016). PGK ditandai dengan memburuknya fungsi ginjal yang tidak dapat dipulihkan (ireversibel), dapat menyebabkan penyakit ginjal stadium akhir yang mengharuskan pengobatan dengan terapi penggantian ginjal seperti transplantasi ginjal atau hemodialisis (Zyoud dkk., 2016).

Data Riset Kesehatan Dasar tahun 2018 menunjukkan bahwa di Indonesia terjadi peningkatan Penyakit Tidak Menular (PTM) dengan prevalensi penduduk Indonesia yang menderita gagal ginjal sebesar $0,4 \%$ atau 4 per 1000 penduduk (Kementerian Kesehatan RI, 2018). Indonesian Renal Registry (IRR) tahun 2018 menyatakan sebanyak 98\% penderita gagal ginjal menjalani terapi hemodialisis (HD) dan $2 \%$ menjalani terapi peritoneal dialisis. Jumlah pasien hemodialisis baik pasien baru maupun pasien aktif mengalami peningkatan dari 77.892 pasien pada tahun 2017 menjadi 132.142 pasien pada tahun 2018 (PERNEFRI, 2018).

Penyakit ginjal kronik merupakan kondisi yang menyebabkan gangguan fisik dan psikologis seperti kecemasan dan stress. Kondisi pasien yang membutuhkan hemodialisis akan memicu berbagai masalah seperti masalah fisik, psikologis, gaya hidup, dan perubahan sosial yang akan berdampak pada penurunan kapasitas fungsional dan kualitas hidup pasien (Tsai dkk., 2010). Sebuah penelitian mengungkapkan bahwa pasien PGK memiliki kualitas hidup yang lebih buruk, resiko rawat inap dan mortalitas yang lebih tinggi dibandingkan dengan populasi umum (Bawazier \& Suhardjono, 2018).

Kualitas hidup pasien PGK dipengaruhi oleh jenis terapi penggantian ginjal. Pasien yang menjalani transplantasi ginjal mencapai kualitas hidup yang lebih baik dibandingkan dengan pasien dialisis. Sedangkan pasien hemodialisis menunjukkan peningkatan skor domain SF-36 lebih besar daripada pasien dengan peritoneal dialisis (Yusop dkk., 2013). Kualitas hidup pasien hemodialisis pada domain kesehatan mental dan kesehatan fisik sangat terkait dengan morbiditas dan mortalitas. Penilaian health related quality of life (HRQoL) pada pasien PGK penting dilakukan sebagai evaluasi terhadap kualitas layanan kesehatan dan efektivitas terapi sehingga dapat meminimalkan keparahan/komplikasi dan HRQoL pasien dapat meningkat (Zyoud dkk., 2016). Salah satu instrumen untuk menilai $\mathrm{HRQoL}$ adalah dengan menggunakan kuesioner KDQoL-SF36 yang merupakan instrumen spesifik untuk menilai kualitas hidup pasien PGK yang menjalani hemodialisis dan direkomendasikan oleh National Kidney Foundation (Yusop dkk., 2013).

Sejumlah studi telah mengidentifikasi faktor-faktor yang mempengaruhi kualitas hidup pasien hemodialisis sebagai dasar untuk menentukan strategi terapi yang tepat. Beberapa faktor yang terkait adalah usia, jenis kelamin, tingkat pendidikan, status pekerjaan, faktor psikososial seperti status pernikahan, depresi dan kecemasan, serta faktor klinik seperti kadar hemoglobin, kreatinin, durasi dialisis, dan adanya penyakit penyerta (Barzegar dkk., 2017; Dehesa-lópez dkk., 2016; Puspitasari dkk., 2019; Yusop dkk., 2013; Zyoud dkk., 2016). Di Indonesia penelitian mengenai hubungan faktor klinik dengan kualitas hidup pasien hemodialisis masih terbatas. Oleh karena itu penelitian ini bertujuan untuk menilai status $\mathrm{HRQ}$ oL pasien dan mengetahui faktor klinik yang berpengaruh terhadap kualitas hidup pasien hemodialisis di RSUD dr. Loekmono Hadi Kudus.

\section{METODE}

\section{Rancangan penelitian}

Penelitian ini menggunakan metode cross sectional yang dilakukan pada bulan Februari - Maret tahun 2020 di Instalasi Hemodialisa RSUD dr. Loekmono Hadi Kudus. Penelitian ini telah memperoleh izin Komisi Etik Penelitian Kesehatan Fakultas Kedokteran Universitas Diponegoro dengan No.496/EC/KEPK/FKUNDIP/XI/2019.

\section{Pengumpulan data}

Pengambilan sampel penelitian menggunakan tehnik total sampling berdasarkan kriteria inklusi dan eksklusi. Kriteria inklusi penelitian adalah pasien yang menjalani hemodialisis rutin dengan frekuensi 2 - 3 kali per minggu, berusia $\geq 18$ tahun, menyetujui informed 
consent dan bersedia mengisi kuesioner. Pasien dengan kondisi umum sangat lemah, tidak kooperatif, dan pasien dengan gangguan mental sedang atau berat yang tidak bisa diajak komunikasi dieksklusi dari penelitian ini.

Data klinik diperoleh dari rekam medik pasien yang meliputi komorbid, lama menjalani hemodialisis, kadar hemoglobin, ureum dan kreatinin yang kemudian diamati pengaruhnya terhadap kualitas hidup pasien. Penilaian kualitas hidup dilakukan melalui wawancara pasien saat dilakukan dialisis dengan menggunakan kuesioner KDQoL-SF36. Data sosiodemografi pasien yang meliputi jenis kelamin, usia, tingkat pendidikan, status pekerjaan dan pernikahan dianalisa sebagai gambaran kualitas hidup pasien.

\section{Alat ukur}

Alat ukur yang digunakan untuk mengukur kualitas hidup adalah kuesioner Kidney Disease Quality of Life Short Form 36 (KDQoL-SF36) yang dikembangkan oleh Research and Development (RAND) dan Universitas Arizona. Berdasarkan Hays dkk. (1997), kuesioner KDQoL-SF36 mempunyai reliabilitas di atas 0,8 untuk pertanyaan terkait penyakit ginjal kecuali aspek fungsi kognitif $(0,68)$ dan aspek interaksi sosial $(0,61)$. Pertanyaan terkait kondisi kesehatan secara umum memiliki reliabilitas 0,78 - 0,92. Hal ini menandakan bahwa kuesioner KDQoL memiliki nilai reliabilitas yang baik.

Kuesioner KDQOL-SF36 sudah dilakukan validasi dan uji reliabilitas dalam berbagai versi bahasa. Penelitian sebelumnya yang dilakukan oleh Supriyadi dkk. (2019) pada 103 pasien PGK di Rumah Sakit Hasan Sadikin Bandung menunjukkan nilai reliabilitas $\geq 0,7$ untuk seluruh skala yang artinya kuesioner ini reliabel untuk menilai kualitas hidup pasien hemodialisis rutin. Kuesioner ini terdiri dari 3 domain dengan 19 parameter. Domain penyakit ginjal terdiri dari parameter gejala, efek dari penyakit ginjal, beban penyakit ginjal, status pekerjaan, fungsi kognitif, kualitas interaksi sosial, fungsi seksual, kualitas tidur, dukungan sosial, kualitas pelayanan staf dialisis serta kepuasan pasien. Domain kesehatan fisik meliputi parameter fungsi fisik, peran fisik, persepsi rasa sakit dan persepsi kesehatan secara umum. Sedangkan domain kesehatan mental terkait dengan parameter emosi, peran emosional, fungsi sosial dan energi/kelelahan. Kualitas hidup pasien dinilai dengan cara menghitung skoring data kuesioner, perhitungan rata-rata pada masing-masing domain dan total nilai kualitas hidup. Skor total secara keseluruhan antara 0 - 100. Semakin tinggi skor yang diperoleh menandakan kualitas hidup yang semakin baik (Hays dkk., 1997).

\section{Analisis data}

Analisis data penelitian menggunakan Statistical Package for the Social Science (SPSS) software version 21. Data disajikan dalam bentuk distribusi frekuensi dan rata-rata \pm standar deviasi (SD). Analisis kualitas hidup berdasar karakteristik sosiodemografi subjek penelitian menggunakan Independent samples t-test atau MannWhitney test untuk membandingkan perbedaan dua kelompok dan one-way ANOVA atau Kruskal Walis test untuk lebih dari dua kelompok. Hubungan antara faktor klinik dengan kualitas hidup menggunakan uji Spearman. Analisis regresi logistik digunakan untuk mengidentifikasi faktor klinik yang paling berpengaruh terhadap kualitas hidup. Tingkat signifikansi yang digunakan dalam penelitian ini adalah $\mathrm{P}<0,05$.

\section{HASIL DAN PEMBAHASAN}

\section{Karakteristik subjek penelitian}

Penelitian ini didapatkan 60 subjek penelitian yakni pasien yang menjalani hemodialisis rutin di Instalasi Hemodialisa RSUD dr. Loekmono Hadi Kudus yang memenuhi kriteria inklusi.

Tabel 1 menunjukkan gambaran karakteristik subjek dalam penelitian ini, dimana jumlah laki-laki (60\%) lebih banyak dari perempuan. Sebagian besar subjek penelitian berada pada rentang usia 45 - 59 tahun (67\%). Hal ini sesuai dengan data dari Indonesian Renal Registry (2018) yang menyebutkan pasien yang menjalani terapi hemodialisis jumlah laki-laki sedikit lebih banyak dibanding perempuan dan proporsi pasien terbanyak pada kategori 45 - 64 tahun.

Subjek dalam penelitian ini lebih dari separuh berpendidikan tingkat menengah $(57 \%)$, berstatus menikah (95\%) dan tidak bekerja (63\%). Hipertensi merupakan komorbid pada sebagian besar subjek (65\%). Penelitian lain juga menemukan hasil serupa bahwa hipertensi dialami oleh 68,9 - 73,5\% subjek (Puspitasari dkk., 2019; Yusop dkk., 2013).

Semua pasien dalam penelitian ini melakukan hemodialisis sebanyak dua kali seminggu dengan durasi 4 - 5 jam. Rata-rata lama menjalani terapi hemodialisis dalam penelitian ini adalah 18 bulan. Sedangkan untuk parameter laboratorium didapatkan rata-rata kadar hemoglobin $8,27 \pm 1,53 \mathrm{~g} / \mathrm{dL}$, ureum $114,98 \pm$ 40,68 mg/dL, dan kreatinin 9,37 $\pm 3,41 \mathrm{mg} / \mathrm{dL}$.

\section{Analisis kualitas hidup pasien hemodialisis}

Rata-rata skor kualitas hidup pasien PGK pada penelitian ini adalah $63,20 \pm 17,05$, lebih rendah jika 
dibandingkan dengan penelitian yang dilakukan oleh Barzegar dkk. (2017). Pada Gambar 1 terlihat skor tertinggi pada domain penyakit ginjal $(74,52 \pm 9,83)$, diikuti domain kesehatan mental $(67,68 \pm 20,10)$ dan yang paling rendah pada domain kesehatan fisik $(47,41$ $\pm 25,09$ ). Parameter yang paling rendah adalah peran fisik dengan nilai 27,50 $\pm 41,35$. Hasil tersebut serupa dengan penelitian yang dilakukan oleh Dehesa-lópez dkk. (2016) bahwa skor domain kesehatan fisik lebih rendah daripada kesehatan mental dengan penurunan nilai paling rendah pada parameter peran fisik. Penelitian lain menyebutkan bahwa nilai skor domain kesehatan fisik yang lebih rendah mencerminkan kemampuan orang untuk beradaptasi secara psikologis dengan situasi mereka dari waktu ke waktu, karena variabel waktu mengurangi aspek fisik kualitas hidup tetapi bukan aspek mental (Guerra-guerrero dkk., 2012; Yusop dkk., 2013). Sebaliknya parameter dengan nilai skor tertinggi pada penelitian ini adalah kualitas pelayanan staf dialisis, hal ini sesuai dengan penelitian yang dilakukan di Rumah Sakit Cipto Mangunkusumo yang menggambarkan bahwa petugas hemodialisis baik dalam memberikan layanan kepada pasien (Bawazier \& Suhardjono, 2018).

Tabel 1. Karakteristik subjek penelitian dan rata-rata skor kualitas hidup

\begin{tabular}{|c|c|c|c|c|}
\hline Karakteristik subjek & Jumlah subjek (n) & Persentase $(\%)$ & Kualitas Hidup (Rata-rata \pm SD) & p-value \\
\hline \multicolumn{5}{|l|}{ Faktor Sosiodemografi } \\
\hline \multicolumn{5}{|l|}{ Jenis Kelamin } \\
\hline Laki-laki & 36 & 60 & $67,60 \pm 16,77$ & \multirow{2}{*}{$0,013^{\mathrm{a}}$} \\
\hline Perempuan & 24 & 40 & $56,60 \pm 15,56$ & \\
\hline \multicolumn{5}{|l|}{ Usia } \\
\hline$\geq 18-44$ tahun & 8 & 13 & $62,93 \pm 15,01$ & \multirow{3}{*}{0,829} \\
\hline $45-59$ tahun & 40 & 67 & $64,04 \pm 18,44$ & \\
\hline$\geq 60$ tahun & 12 & 20 & $60,57 \pm 14,14$ & \\
\hline \multicolumn{5}{|l|}{ Tingkat Pendidikan } \\
\hline Tingkat dasar & 15 & 25 & $60,57 \pm 12,02$ & \multirow[t]{3}{*}{$0,189^{d}$} \\
\hline Tingkat menengah & 34 & 57 & $61,64 \pm 19,15$ & \\
\hline Tingkat atas & 11 & 18 & $71,61 \pm 14,39$ & \\
\hline \multicolumn{5}{|l|}{ Status Pekerjaan } \\
\hline Bekerja & 22 & 37 & $77,65 \pm 16,10$ & \multirow[t]{2}{*}{$0,000^{b}$} \\
\hline Tidak bekerja & 38 & 63 & $54,84 \pm 10,98$ & \\
\hline \multicolumn{5}{|l|}{ Status Pernikahan } \\
\hline Menikah & 57 & 95 & $63,87 \pm 17,07$ & \multirow[t]{2}{*}{$0,190^{\mathrm{a}}$} \\
\hline Tidak menikah & 3 & 5 & $50,55 \pm 12,90$ & \\
\hline \multicolumn{5}{|l|}{ Faktor Klinik } \\
\hline \multicolumn{5}{|l|}{ Komorbid } \\
\hline Hipertensi & 39 & 65 & $65,06 \pm 17,47$ & \multirow[t]{4}{*}{$0,253^{\mathrm{a}}$} \\
\hline $\begin{array}{l}\text { Hipertensi-Diabetes } \\
\text { melitus }\end{array}$ & 21 & 35 & $59,74 \pm 16,09$ & \\
\hline \multicolumn{4}{|l|}{ Lama Menjalani Terapi } & \\
\hline \multicolumn{4}{|l|}{ HD } & \\
\hline$<1$ tahun & 23 & 38 & $58,19 \pm 14,07$ & $0,017^{\mathrm{c}}$ \\
\hline $1-<2$ tahun & 20 & 33 & $67,07 \pm 16,86$ & \\
\hline $2-<3$ tahun & 7 & 12 & $77,99 \pm 16,72$ & \\
\hline$\geq 3$ tahun & 10 & 17 & $56,65 \pm 17,92$ & \\
\hline Parameter Laboratorium & & & Rata-rata $\pm \mathrm{SD}$ & \\
\hline Hemoglobin (g/dL) & 60 & & $8,27 \pm 1,53$ & \\
\hline Ureum (mg/dL) & 60 & & $114,98 \pm 40,68$ & \\
\hline Creatinin $(\mathrm{mg} / \mathrm{dL})$ & 60 & & $9,37 \pm 3,41$ & \\
\hline
\end{tabular}

Keterangan:

p: taraf kepercayaan $5 \%(\mathrm{p}<0,05) ; \ldots{ }^{\mathrm{a}}$ : analisis menggunakan Independet-samples $t$-test $; \ldots{ }^{\mathrm{b}}:$ analisis menggunakan Mann Whitney Test $;{ }^{c}{ }^{\mathrm{c}}$ : analisis menggunakan One way-Anova $; . .{ }^{\mathrm{d}}:$ analisis menggunakan Kruskal Walis Test; Huruf yang dicetak tebal menunjukkan adanya perbedaan yang signifikan dalam kelompok 


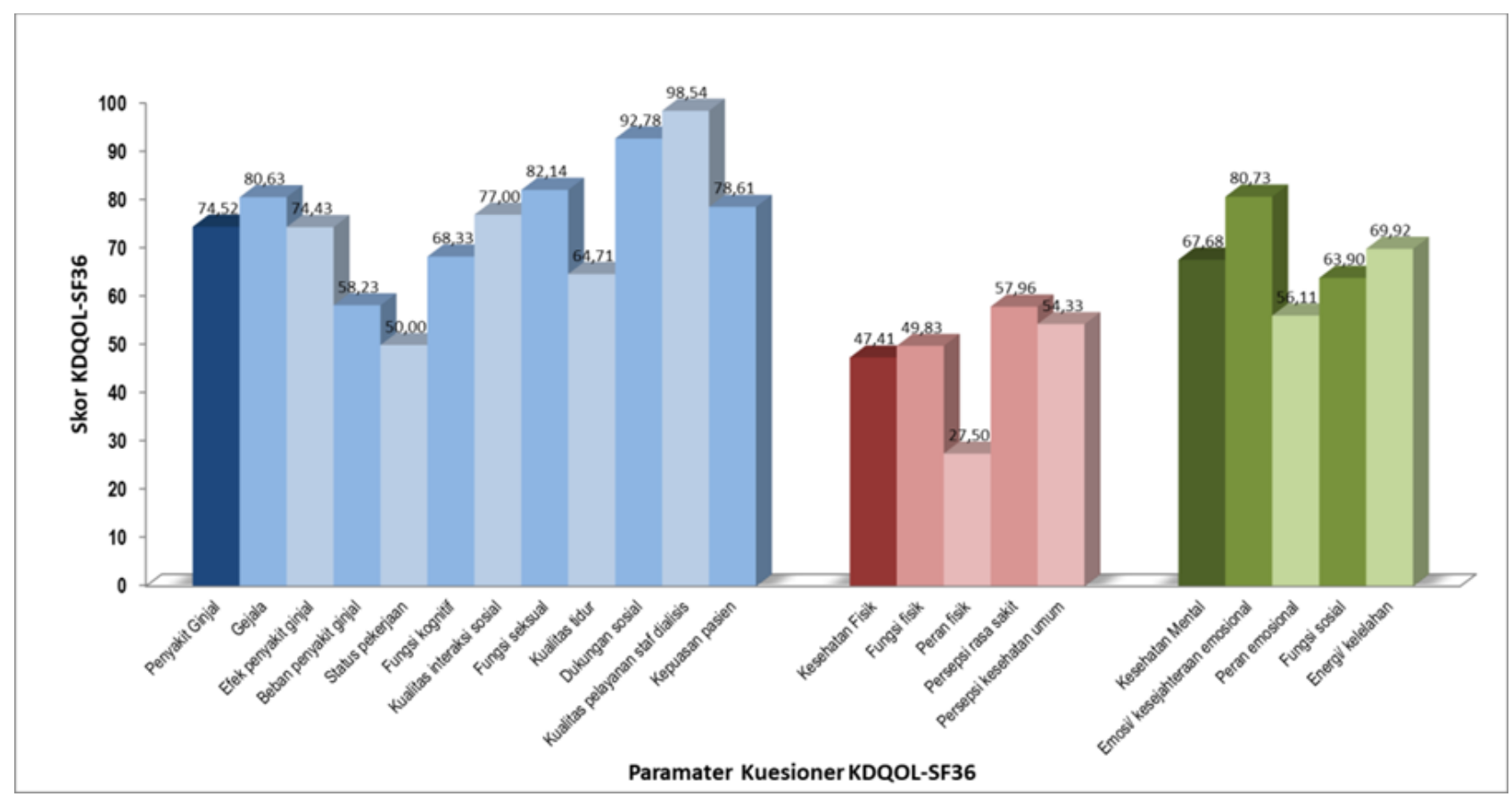

Gambar 1. Rata-rata skor tiap parameter KDQoL-SF36

Pada uji beda kategori jenis kelamin (Tabel 1) terdapat perbedaan yang bermakna, skor kualitas hidup laki-laki $(67,60 \pm 16,77)$ lebih tinggi dibanding perempuan $(56,60 \pm 15,56)$. Hasil penelitian ini sesuai dengan yang dilakukan oleh Zyoud dkk. (2016) yang menjelaskan bahwa perempuan di negara berkembang memiliki kehidupan sosial dan aktivitas fisik yang lebih rendah. Selain itu laki-laki lebih kecil kemungkinan untuk merasa cemas atau tertekan dibandingkan perempuan sehingga perempuan cenderung memiliki kualitas hidup yang buruk.

Usia merupakan salah satu prediktor penting dalam kualitas hidup dan memiliki hubungan yang signifikan dengan korelasi negatif di mana kualitas hidup akan menurun dengan bertambahnya usia pada pasien hemodialisis (Barzegar dkk., 2017). Begitu pula pada penelitian ini kelompok usia $\geq 60$ tahun memiliki skor kualitas hidup paling rendah namun secara statistik tidak memiliki hubungan yang signifikan antara usia dengan kualitas hidup. Penelitian lain melaporkan bahwa pasien dengan usia lebih tua menunjukkan tingkat kepuasan yang lebih besar terhadap status kesehatan dan sosialnya serta dapat menerima kondisi dialisis yang mereka jalani jika dibandingkan dengan pasien yang lebih muda (Ayoub \& Hijjazi, 2013).

Pada variabel tingkat pendidikan, tidak terdapat perbedaan bermakna antar kelompok, namun pada subjek dengan tingkat pendidikan atas $(71,61 \pm 14,39)$ memiliki kualitas hidup yang lebih tinggi dibanding pendidikan dasar $(60,57 \pm 12,02)$ dan menengah
$(61,64 \pm 19,15)$. Hal ini disebabkan karena pasien yang berpendidikan tinggi memiliki pemahaman yang lebih baik tentang penyakit, dampak dari penyakit dan pengobatannya atau karena mereka dapat memperoleh informasi yang lebih tentang terapi PGK, lebih patuh dalam pengobatan dan memiliki hubungan yang lebih baik dengan petugas kesehatan (Zyoud dkk., 2016).

Pekerjaan menjadi faktor penting dan berpengaruh signifikan terhadap kualitas hidup. Subjek dengan status bekerja $(77,65 \pm 16,10)$ memiliki kualitas hidup lebih baik daripada yang tidak bekerja $(54,84 \pm 10,98)$. Subjek yang bekerja dapat menunjukkan kemampuannya, memiliki citra diri yang lebih baik, penampilan, dan harga diri yang dapat meningkatkan kualitas hidup mereka (Anees dkk., 2014). Dalam penelitian lain juga menyebutkan bahwa subjek yang tidak bekerja secara signifikan berpengaruh terhadap penurunan HRQoL pada pasien hemodialisis (Zyoud dkk., 2016).

Pada uji perbedaan kelompok status pernikahan dalam Tabel 1, tidak terdapat perbedaan bermakna pada kelompok menikah dan tidak menikah, namun kualitas hidup subjek menikah $(63,87 \pm 17,07)$ lebih tinggi dibanding yang tidak menikah $(50,55 \pm 12,90)$. Hasil ini serupa dengan penelitian yang dilakukan oleh Ayoub \& Hijjazi (2013). Status pernikahan dalam penelitian ini tidak memberikan hasil yang signifikan kemungkinan disebabkan karena hampir semua subjek penelitian berstatus menikah (95\%). Tiga orang yang berstatus tidak menikah belum cukup menggambarkan pengaruh status pernikahan terhadap kualitas hidup mereka. 
Tabel 2. Hubungan antara faktor klinik dengan rata-rata skor tiap domain KDQoL-SF36

\begin{tabular}{lccccc}
\hline \multirow{2}{*}{ Domain KDQOL-SF36 } & \multicolumn{5}{c}{ Koefisien korelasi (r) } \\
\cline { 2 - 6 } & Komorbid & Durasi HD & Hb & Ureum & Kreatinin \\
\hline Penyakit Ginjal & $-0,213$ & 0,205 & 0,027 & 0,079 & 0,228 \\
Kesehatan Fisik & $-0,161$ & $0,319^{*}$ & 0,175 & 0,129 & $0,258^{*}$ \\
Kesehatan Mental & $-0,133$ & 0,118 & 0,092 & 0,020 & 0,175 \\
Total Skor Kualitas Hidup & $-0,148$ & 0,211 & 0,123 & 0,077 & 0,243 \\
\hline
\end{tabular}

Keterangan:

*nilai signifikansi 0,05; Analisis menggunakan uji korelasi Spearman

Tabel 3. Analisis regresi logistik faktor klinik terhadap kualitas hidup

\begin{tabular}{|c|c|c|c|c|}
\hline \multirow{2}{*}{ Variabel } & \multirow{2}{*}{ OR } & \multicolumn{2}{|c|}{$95 \% C I$} & \multirow{2}{*}{$p$-value } \\
\hline & & Lower & Upper & \\
\hline Komorbid (HT vs. HT-DM) & 0,502 & 0,139 & 1,819 & 0,294 \\
\hline Durasi HD ( $\leq 18$ vs. $>18$ bulan $)$ & 2,009 & 0,765 & 7,187 & 0,266 \\
\hline Kadar $\mathrm{Hb}(\leq 8$ vs. $>8 \mathrm{~g} / \mathrm{dL})$ & 2,344 & 0,765 & 7,187 & 0,136 \\
\hline Kadar Ureum ( $\leq 115$ vs. $>115 \mathrm{mg} / \mathrm{dL})$ & 1,742 & 0,546 & 5,555 & 0,348 \\
\hline $\operatorname{Kadar} \operatorname{Kreatinin}(\leq 9,5$ vs. $>9,5 \mathrm{mg} / \mathrm{dL})$ & 1,533 & 0,488 & 4,817 & 0,465 \\
\hline
\end{tabular}

Keterangan:

OR : odds ratio; $\mathrm{CI}=$ confidence intervall; $\mathrm{HT}=$ hipertensi; $\mathrm{HT}-\mathrm{DM}=$ hipertensi-diabetes mellitus

\section{Hubungan faktor klinis terhadap kualitas hidup}

Faktor klinis seperti adanya penyakit penyerta, lama menjalani terapi (durasi) HD, anemia, dan kadar kreatinin telah diakui sebagai variabel yang berhubungan dengan HRQoL. Untuk melihat hubungan faktor klinik yang digunakan dalam penelitian ini dengan rata-rata skor tiap domain KDQoL-SF36 dianalisis menggunakan koefisien korelasi Spearman seperti tersaji pada Tabel 2. Hasil dalam penelitian ini menunjukkan korelasi yang lemah pada hampir semua parameter klinik dengan rata-rata skor domain KDQoLSF36.

Penyakit penyerta (komorbid) berkorelasi lemah dan bernilai negatif terhadap domain penyakit ginjal ( $r=-0,213)$, kesehatan fisik $(r=-0,161)$, kesehatan mental $(r=-0,133)$ dan total skor kualitas hidup $(r=-0,148)$. Korelasi negatif artinya dengan semakin banyak penyakit penyerta yang diderita pasien maka akan menurunkan kualitas hidup pasien hemodialisis. Korelasi serupa telah diamati dalam penelitian sebelumnya yang menyatakan adanya komorbid terutama diabetes melitus, sangat terkait dengan penurunan nilai kualitas hidup pasien hemodialisis (Ayoub \& Hijjazi, 2013; Griva dkk., 2015). Skor kualitas hidup subjek pada penelitian ini yang disertai komorbid hipertensi-diabetes $(59,74 \pm 16,09)$ lebih rendah dibanding subjek dengan komorbid hipertensi saja $(65,06 \pm 17,47)$. Penelitian yang dilakukan oleh Guerra-guerrero, dkk (2012) dan Yusop, dkk (2013) memberikan hasil yang sama bahwa domain kesehatan mental dan status kesehatan secara keseluruhan lebih baik pada subjek yang tidak disertai komorbid diabetes. Pasien hemodialisis dengan komorbid diabetes memiliki tingkat morbiditas dan mortalitas yang lebih tinggi karena komplikasi mikrovaskuler dan makrovaskuler jika dibandingkan dengan pasien non-diabetes.

Seperti halnya penyakit penyerta, durasi atau lama menjalani terapi hemodialisis dalam penelitian ini juga menunjukkan korelasi yang lemah terhadap rata-rata skor domain KDQoL-SF36 kecuali pada domain kesehatan fisik yang menghasilkan hubungan yang moderat $(r=0,319)$ dan bersifat positif. Korelasi positif ini menunjukkan bahwa semakin lama durasi pasien menjalani terapi hemodialisis maka kualitas hidupnya semakin meningkat. Hal ini ditunjukkan dengan hasil penelitian ini bahwa skor kualitas hidup subjek dengan durasi <1 tahun sebesar 58,19 $\pm 14,07$ kemudian dengan meningkatnya durasi, skor kualitas hidup juga semakin tinggi yakni 67,07 $\pm 16,86$ (durasi $1-<2$ tahun) dan $77,99 \pm 16,72$ (durasi $2-<3$ tahun). Skor terendah terdapat pada subjek dengan durasi $\geq 3$ tahun sebesar $56,65 \pm 17,92$.

Subjek dengan durasi HD $<1$ tahun mempunyai kualitas hidup yang relatif rendah kemungkinan disebabkan karena pasien masih beradaptasi secara fisik maupun mental terhadap kondisi penyakit dan dialisis yang harus mereka jalani. Dengan meningkatnya durasi pasien menjalani terapi hemodialisis, kualitas hidup membaik karena pasien sudah beradaptasi dengan kondisi mereka dan mungkin karena kadar uremia menurun dari waktu ke waktu bersamaan dengan berkurangnya gejala yang dirasakan (Guerra-guerrero 
dkk., 2012). Penelitian lain yang dilakukan oleh Barzegar dkk. (2017) menunjukkan bahwa pasien dengan durasi hemodialisis lebih dari 3 tahun dapat menurunkan kualitas hidup pasien. Selain itu durasi penyakit yang lebih lama, adanya penyakit yang menyertai, bertambahnya usia dan komplikasi yang sulit dikontrol dapat menyebabkan menurunnya kualitas hidup.

Korelasi yang lemah $(r<0,2)$ juga dihasilkan pada hubungan antara kadar hemoglobin dengan rata-rata skor domain KDQoL-SF36 pada penelitian ini (Tabel 2). Korelasi tersebut bernilai positif artinya dengan semakin meningkatnya kadar hemoglobin maka kualitas hidup pasien juga mengalami peningkatan. Kondisi anemia (rendahnya kadar hemoglobin) sering dialami oleh pasien hemodialisis karena defisiensi besi, asam folat dan berkurangnya hormon eritropoetin. Anemia memiliki efek negatif pada HRQoL yang dapat menurunkan kemampuan fungsional pasien seperti penurunan energi dan aktivitas, penurunan kualitas tidur, status kesehatan secara umum, gangguan seksual dan kelemahan otot (Ayoub \& Hijjazi, 2013). Oleh karena itu terapi untuk mengoptimalkan kadar hemoglobin mencapai target $\mathrm{Hb} 10-12 \mathrm{~g} / \mathrm{dL}$ menjadi sangat penting dalam perawatan pasien hemodialisis.

Hasil dalam penelitian ini serupa dengan hasil pada penelitian sebelumnya yang menunjukkan bahwa kadar hemoglobin memiliki hubungan yang tidak signifikan dengan skor kualitas hidup (Dehesa-lópez dkk., 2016; Kim dkk., 2018; Tanod dkk., 2018). Meskipun menunjukkan korelasi yang lemah namun hasil skor kualitas hidup pada penelitian ini sesuai dengan peningkatan kadar $\mathrm{Hb}$ yakni subjek dengan kadar $\mathrm{Hb}>8 \mathrm{~g} / \mathrm{dL}(65,41 \pm 19,50)$ memiliki rata-rata skor kualitas hidup yang lebih tinggi dibanding pada subjek dengan kadar $\mathrm{Hb} \leq 8 \mathrm{~g} / \mathrm{dL}(60,99 \pm 14,19)$. Hal ini menunjukkan terdapat peningkatan skor kualitas hidup seiring meningkatnya kadar $\mathrm{Hb}$ pasien.

Pada variabel kadar ureum juga didapatkan korelasi yang lemah $(r<0,2)$ terhadap rata-rata skor kualitas hidup. Sama halnya pada hubungan antara kadar kreatinin dengan rata-rata skor domain penyakit ginjal $(r=0,228)$, kesehatan fisik $(r=0,258)$, kesehatan mental $(\mathrm{r}=0,175)$ dan total skor kualitas hidup $(\mathrm{r}=0,243)$. Namun demikian hasil dalam penelitian ini sejalan dengan sifat korelasi yang bernilai positif artinya dengan peningkatan kadar ureum dan kreatinin maka kualitas hidup akan meningkat. Koefisien korelasi terbesar terletak pada domain kesehatan fisik. Hal ini juga terlihat pada skor kualitas hidup subjek pada domain kesehatan fisik, yang menunjukkan skor yang lebih rendah pada subjek dengan kadar kreatinin $\leq 9,5 \mathrm{mg} / \mathrm{dL}(41,78 \pm 23,90)$ jika dibandingkan dengan kadar kreatinin > 9,5 mg/dL $(53,84 \pm 25,28)$. Hasil serupa dilaporkan pada penelitian yang dilakukan oleh Ayoub \& Hijjazi (2013) dan Yusop dkk. (2013) bahwa kadar kreatinin serum yang tinggi dikaitkan dengan domain kesehaan fisik yang lebih baik. Kadar kreatinin serum sebanding dengan asupan protein dan massa otot. Hubungan antara kadar kreatinin yang tinggi dengan domain kesehatan fisik yang lebih baik disebabkan karena memiliki komposisi otot yang lebih baik terutama di tungkai bawah.

Untuk mengidentifikasi faktor klinik yang paling berpengaruh terhadap skor kualitas hidup pada penelitian ini dianalisis menggunakan uji regresi logistik seperti tersaji pada Tabel 3. Berdasarkan analisis regresi logistik menunjukkan tidak terdapat faktor klinik yang signifikan paling berpengaruh terhadap kualitas hidup subjek pada penelitian ini.

Terdapat penelitian sebelumnya yang sejalan dengan penelitian ini yang mengidentifikasi hubungan antara parameter biokimia dengan skor kualitas hidup pasien hemodialisis menggunakan instrumen KDQoLSF36. Hasil dalam penelitian itu menyebutkan tidak terdapat hubungan yang signifikan pada variabel bebas (kalsium, fosfat, urea, hormon paratiroid, albumin, hemoglobin dan durasi hemodialisis) dengan kelima parameter KDQOL-SF36 (gejala, efek penyakit ginjal, beban penyakit ginjal, kesehatan fisik dan mental) (Saad dkk., 2015). Penelitian lainnya yang dilakukan oleh Dehesa-lópez dkk. (2016) juga mendapatkan hasil bahwa tidak ditemukan korelasi yang kuat antara faktor klinik dan parameter laboratorium dengan HRQoL pasien hemodialisis. Parameter biokimia tidak dapat mencerminkan kesehatan fisik dan mental akibat penyakit ginjal, dan tantangan dalam perawatan pasien hemodialisis membutuhkan kolaborasi tenaga kesehatan dari berbagai disiplin ilmu untuk mencapai kualitas hidup pasien yang lebih baik.

\section{Kekuatan dan keterbatasan penelitian}

Penelitian ini memiliki beberapa kekuatan diantaranya penggunaan kuesioner KDQoL-SF36 yang merupakan instrumen spesifik yang reliabel untuk mengukur kualitas hidup pasien PGK yang menjalani dialisis. Selain itu pengambilan data dilakukan dengan wawancara tatap muka untuk mendapatkan data yang lebih lengkap meskipun dapat terjadi bias pada hasil wawancara. Hasil dari penelitian yang didasarkan dari satu tempat penelitian menyebabkan hasil penelitian ini 
memiliki tingkat generalisasi yang rendah merupakan keterbatasan dalam penelitian ini.

\section{KESIMPULAN}

Hasil dalam penelitian ini menunjukkan tidak ada korelasi yang kuat dan tidak terdapat faktor klinik yang secara signifikan paling berpengaruh terhadap kualitas hidup pasien. Meskipun demikian penelitian ini diharapkan dapat digunakan sebagai salah satu referensi dalam perawatan pasien hemodialisis. Hasil pengukuran klinik dari pemeriksaan laboratorium merupakan informasi penting bagi dokter untuk melihat luaran klinik pasien, namun parameter tersebut berkorelasi lemah terhadap kualitas hidup. Perawatan komprehensif bagi pasien hemodialisis harus mencakup penilaian HRQoL sebagai ukuran kecukupan dialisis dan tidak terbatas hanya pada pengukuran parameter klinis. Dibutuhkan kolaborasi tenaga kesehatan dalam perawatan pasien untuk mengoptimalkan terapi dan meningkatkan HRQoL pasien.

\section{DAFTAR PUSTAKA}

Anees, M., Riaz Malik, M., Abbasi, T., Nasir, Z., Hussain, Y. \& Ibrahim, M. (2014). Demographic Factors Affecting Quality of Life of Hemodialysis Patients. Pakistan Journal of Medical Sciences; 30; 1123-1127.

Ayoub, A. M. \& Hijjazi, K. H. (2013). Quality of Life in Dialysis Patients from the United Arab Emirates. Journal of Family and Community Medicine; 20; 106-112.

Barzegar, H., Jafari, H., Charati, J. Y. \& Esmaeili, R. (2017). Relationship Between Duration of Dialysis and Quality of Life in Hemodialysis Patients. Iranian Journal of Psychiatry and Behavioral Sciences; 11; e6409.

Bawazier, L. A. \& Suhardjono. (2018). Comparison of Quality of Life between Patients Undergoing Chronic Hemodialysis with Reusable Dialyzer and Single-Use Dialyzer: A Retrospective Cohort Study. Indonesian Journal of Internal Medicine; 50; 222-229.

Dehesa-lópez, E., Correa-rotter, R., Olvera-castillo, D., González-parra, C. \& Baizabal-olarte, R. (2016). CLinical, Dialytic and Laboartory Factors Associated with Poor Health-Related Quality of Life in Mexican Patients on Hemodialysis. Revista De Investigacion Clinica; 68; 192-200.

Griva, F. Y. K., Vathsala, T. L. A. \& Ng, E. L. H. J. (2015). Health-Related Quality of Life of Asian
Patients with End-Stage Renal Disease (ESRD) in Singapore. Quality of Life Research; 24; 2163-2171.

Guerra-guerrero, V., Sanhueza-alvarado, O. \& Caceresespina, M. (2012). Quality of Life in People with Chronic Hemodialysis: Association with. Revista Latino-Americana de Enfermagem; 20; 838-846.

Hays, R. D., Kallich, J. D., Mapes, D. L., Coons, S. J., Amin, N., Carter, W. B. \& Kamberg, C. (1997). Kidney Disease Quality of Life Short Form (KDQOL-SF) Version 1.3: A Manual for Use and Scoring. Quality of Life Research; 3; 329-380.

Kementerian Kesehatan RI. (2018). Laporan Riset Kesehatan Dasar Indonesia Tahun 2018. Jakarta: Kementrian Kesehatan RI.

Kim, K., Kang, G. W. \& Woo, J. (2018). The Quality of Life of Hemodialysis Patients is Affected Not Only by Medical but also Psychosocial Factors: a Canonical Correlation Study. Journal Korean Medical Science; 33; 1-11.

Perhimpunan Nefrologi Indonesia (PERNEFRI). (2018). 11th Report of Indonesian Renal Registry 2018. Jakarta: Perhimpunan Nefrologi Indonesia. Puspitasari, C. E., Andayani, T. M. \& Irijanto, F. (2019). Penilaian Kualitas Hidup Pasien Hemodialisis Rutin dengan Anemia di Yogyakarta. Jurnal of Management and Pharmacy Practice; 9; 182191.

Saad, M. M., Douaihy, Y. El, Boumitri, C., Moussaly, E., Daoud, M., Rondla, C. \& Sayegh, S. E. El. (2015). Predictors of Quality of Life in Patients with End-Stage Renal Disease on Hemodialysis. International Journal of Nephrology and Renovascular Disease; 8; 119-123.

Supriyadi, R., Rakhima, F. \& Gondodiputro, R. S. (2019). Validity and Reliability of the Indonesian Version of Kidney Disease Quality of Life (KDQOL-36) Questionnaire in Hemodialysis Patients at Hasan Sadikin Hospital, Bandung, Indonesia. The Indonesian Journal of Internal Medicine; 51; 318-323.

Tanod, D. V., Rotty, L., Palar, S. \& Moeis, E. (2018). Correlation between Hemoglobin, Serum Albumin, Body Mass Index, Hemodialysis Shift Time and Hemodialysis Adequacy with Quality of Life in Hemodialysis Patients. Indonesian Journal of Kidney and Hypertension; I; 13-17.

Tsai, Y., Hung, C., Hwang, S., Wang, S., Hsiao, S., Lin, M., Kung, L., Hsiao, P. \& Chen, H. (2010). Quality of Life Predicts Risks of End-Stage Renal 
Disease and Mortality in Patients with Chronic Kidney Disease. Nephrology, Dialysis, Transplantation; 25; 1621-1626.

Yusop, N. B. M., Mun, C. Y., Shariff, Z. M. \& Huat, C. B. (2013). Factors Associated with Quality of Life Among Hemodialysis Patients in Malaysia. PLOS ONE; 8; 1-11.
Zyoud, S. H., Daraghmeh, D. N., Mezyed, D. O., Khdeir, R. L., Sawafta, M. N., Ayaseh, N. A., Tabeeb, G. H., Sweileh, W. M., Wang, R. \& Aljabi, S. W. (2016). Factors Affecting Quality of Life in Patients on Haemodialysis: a CrossSectional Study from Palestine. $B M C$ Nephrology; 17; 1-12. 